\title{
BOX 27
}

A question of definition.

\section{BY KEVIN LAUDERDALE}

"W

elcome to Galactic Confederation processing. Please state your name."

The creature behind the counter - they used actual counters, even this deep in the heart of the Galaxy - looked like a giant chartreuse bear with black fins running down her spine. Marta assumed the bear was a she. The translator certainly produced a female voice. The bear wasn't wearing a name tag or anything.

"Ambassador Marta Rilla-Chen," Marta replied clearly and directly. "Of the Earth Diplomatic Corps." She was there to present her credentials to the Confederation. But the ceremony wasn't being held in a throne room or a hall bedecked with ceremonial splendour. She was in an office of some sort, whose multiple counters and flickering lighting reminded her of the fluorescents in the DMV back home. Only the view of the swirling Galactic core out of the windows and the presence of dozens of different types of aliens around her broke the illusion. Still, she couldn't help but wonder if some of those other aliens in the office were there to pay parking tickets.

"Form, please," growled the bear in a bored monotone, and Marta handed over the flexiplast pages. The bear ran her eyes down the form. She stamped an item here and circled an item there with a laser pen. She stopped and looked up from the form. With pronounced disapproval she said: "You didn't fill in Box 27."

Marta had been expecting that. "Right," she said. "I wasn't sure what to put down. What does 'Society Code' mean?"

The bear sighed. "Every member species has a specific number and name." Marta found the droning quality of her rough voice actually quite charming. The bear had given this speech, what, a thousand times before? That's how many member worlds were in the Confederation. "We'll assign your catalogue number, but you need to provide the name you will all be known by."

Marta felt confused. Her face must have shown it.

The bear said: "I can see we'll have to go through the whole zarfasnop. Let's try to

$\rightarrow$ NATURE.COM Follow Futures: @ @NatureFutures f go.nature.com/mtoodm make this quick. Says here your planet's name is Earth. Does that mean anything in particular?"

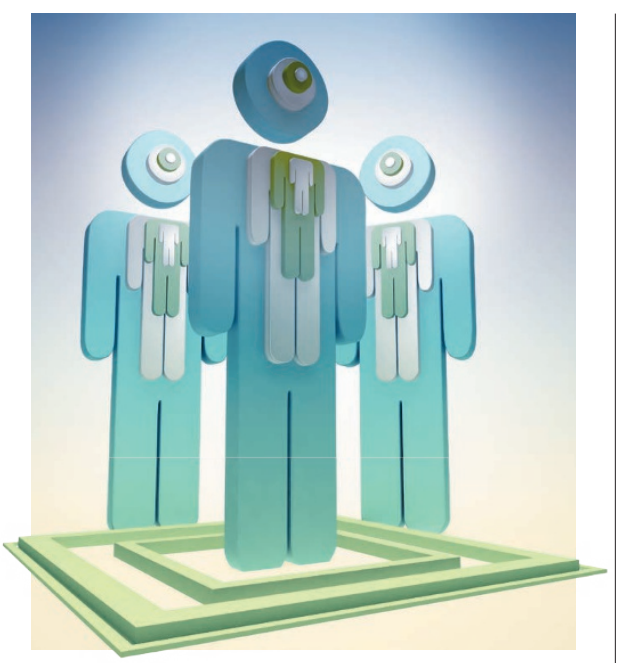

"Ummm, land, soil, dirt."

“Oh yeah. I’ve heard about your planet. Earth is the place with all the water, but you named it Dirt. Makes a lot of sense. How about if you call yourselves The Crazies. That's short at least. Raljevanites call themselves We Who Created The Ice-Based Food That Is Sweet But Causes Your Head To Hurt. That's their planet's claim to fame and they're sticking with it for all it's worth. If you were from Melton II, you would be part of The Survivors. That's nice. Also short. Anyway, The Crazies, then?" Her pen hovered over the form.

"Wait!" cried Marta. The Crazies! She could just hear her boss exploding over that. Forget her boss - the 8 billion people of Earth would not be pleased that the rest of the Galaxy would know them as The Crazies. "Let's try something else. Ummm, we also call ourselves Terrans."

"What does that mean?"

"People who live on Terra ... Oh, but that just means land."

"Which is dirt. The Dirties?"

Marta shook her head. "Oh! Of course! We call ourselves People." Why hadn't she thought of that in the first place? That was better. That was respectable.

The bear snorted. "Everyone calls themselves People. My people call themselves People. That guy over there from Aquatox IV wearing the glass bowl that keeps his head immersed in water, calls his fellow creatures People. You'll have to try harder."

Marta thought. "All right. We are ... Homo sapiens. The Wise Man. And Woman. Technically we're Homo sapiens sapiens. So how about The Really Wise People?"
"Didn't your planet almost blow itself up with nuclear weapons -"

"But we didn't."

"- and then almost destroy itself through overheating?"

"But we didn't." Still, she could see the bear's point. Humans had eventually mastered atomic power constructively, restored the planet's ecology, and made it to the stars. Now they were even joining a confederation of fellow space-farers. We had come far, but perhaps it was stretching it a bit to wish to be known as Really Wise.

"Besides," said the bear. "The Really Wise People is already taken."

"By whom?" Marta was indignant. Who could be so egotistical as to actually use that?

The bear gave a wry, growling chuckle. "My People."

Marta shook her long black hair and composed herself. "All right... oh! The Humans!"

"What does that mean?"

Marta sighed. "People."

"Your species has a real talent for circular thought. You want to reconsider The Crazies?"

"No." Marta closed her eyes and concentrated hard. Humans were indeed crazy, dirty, noisy, lovable, brilliant, joyous ... Marta wasn't getting anywhere. This was frustrating. She looked at the bear. "What's your name?" She couldn't keep on thinking of this Really Wise Person as a bear.

"Why do you want to know?"

"It's what humans do. We connect."

"I am called Weylo."

"Hi, Weylo." Marta smiled. "Truth is, we humans don't really know who we are. We're just beginning to figure that out. That's partly why we're out here. Each of us is a human, but we're really at our best when we're connected. It's the things we do together that makes us Humanity."

"Humanity?"

"Yeah, Humanity." That was it. It meant not just all of us, but all of us connected.

"At least it's short." Was that a smile on Weylo's muzzle? She gave the form one final, resounding stamp. "Welcome to the Galactic Confederation, Marta Rilla-Chen ... and Humanity."

Kevin Lauderdale's fiction has appeared in several of Pocket Books'Star Trek anthologies as well as numerous cross-genre collections. Visit him at KevinLauderdale. Livejournal.com. 